\title{
30. RADIOMETRIC AGE DETERMINATIONS FOR BASEMENT FROM SITES 765 AND 766, ARGO ABYSSAL PLAIN AND NORTHWESTERN AUSTRALIAN MARGIN ${ }^{1}$
}

\author{
John N. Ludden ${ }^{2}$
}

\begin{abstract}
The results of experiments in ${ }^{40} \mathrm{Ar} /{ }^{39} \mathrm{Ar}$ age dating using fresh basement material from Sites 765 and 766 of Leg 123 of the Ocean Drilling Program are inconsistent and cannot be used to constrain the basement age of the Argo Abyssal Plain in the Indian Ocean. However, a celadonite sample, which was precipitated during a low-temperature alteration event that affected the basement at Site 765 , yielded a $\mathrm{K}-\mathrm{Ar}$ age of $155.3 \pm 3.4 \mathrm{Ma}$. Celadonites, which have been dated using $\mathrm{Rb}-\mathrm{Sr}$ methods for basement in the Atlantic Ocean (Staudigel et al., 1981) and by K-Ar methods for the Troodos Ophiolite (Staudigel et al., 1986), and for sediments from the Pacific Ocean (Peterson et al., 1986) yield ages that are up to 15 Ma younger than the age for the formation of basement. Thus, the celadonite age is retained as a reliable minimum age for basement at Site 765 . This radiometric age is inconsistent with biostratigraphic ages, which indicate a maximum of late Berriasian (approximately $140 \mathrm{Ma}$ ) for Site 765 , but is consistent with geophysical interpretations of marine magnetic anomalies and with the early north-south seafloor spreading history of the Argo Abyssal Plain region of the Indian Ocean.
\end{abstract}

\section{INTRODUCTION}

Sites 765 and 766 (Fig. 1) were drilled during Leg 123 of the Ocean Drilling Program. Site 765 is located in the Argo Abyssal Plain, approximately $50 \mathrm{~km}$ from the ocean/continent boundary of the northwestern Australian margin. Site 766 is located at the extreme edge of the same continental margin and faces the Cuvier Abyssal Plain. Detailed analysis of these two sites are presented here and in Ludden, Gradstein, et al. (1990). Site 765 was proposed as a drilling location because it represents the earliest oceanic crust formed in the Indian Ocean (Late Jurassic). The sedimentary section at this site is relatively thin (approximately $1000 \mathrm{~m}$ ) and records the Late Jurassic rifting and subsequent sedimentation of the northwestern Australian passive margin. Site 766 is located on crust having transitional geophysical properties (Buffler et al., this volume); drilling was undertaken to determine the nature of sediments overlying the crust and the nature of the acoustic basement.

Magnetic anomaly interpretations (Sager, this volume) indicate that the basement at Site 765 corresponds to marine magnetic anomalies M25 through M26 (early Kimmeridgian to Oxfordian age). Based on the 1983 DNAG compilation (Palmer, 1983), these stratigraphic ages correspond to approximately $160 \mathrm{Ma}$. However, biostratigraphic ages indicate a maximum age of late Berriasian (approximately $140 \mathrm{Ma}$ ). In fact, the biostratigraphic ages for Site 765 and DSDP Site 261 (Fig. 1) are approximately the same, which poses a problem when interpreting the apparent northward opening of the Argo Abyssal Plain (Sager, this volume). Several questions about erosion and the absence of well-preserved biostratigraphic markers of the lowermost sediments have been cited to explain this inconsistency (Gradstein et al., this volume).

This study presents the results of a radiometric dating program that was undertaken for basement samples. Two basaltic samples from Site 765 were dated by ${ }^{40} \mathrm{Ar} /{ }^{39} \mathrm{Ar}$ incremental heating ex-

\footnotetext{
${ }^{1}$ Gradstein, F. M., Ludden, J. N., et al., 1992. Proc. ODP, Sci. Results, 123: College Station, TX (Ocean Drilling Program).

2 Terrestrial Magmatism Research Group, Montréal and Département de Géologie, Université de Montréal, C.P. 6128, Succursale “A," Montréal, Québec H3C 3J7, Canada.
}

periments, and a celadonite vein was dated by $\mathrm{K} / \mathrm{Ar}$. One sample from a diabase sill from Site 766 was dated using ${ }^{40} \mathrm{Ar} /{ }^{39} \mathrm{Ar}$.

\section{NATURE OF BASEMENT MATERIAL}

Details of basement lithologies are described in Ludden, Gradstein, et al. (1990) and in Ishiwatari (this volume). In addition, the effects of low-temperature alteration are discussed by Gillis et al. (this volume). General geochemical characteristics and the petrogenesis of the basalts sampled at both Sites 765 and 766 are discussed by Ishiwatari (this volume) and Ludden and Dionne (this volume).

At Site 765 , drilling in Holes $765 \mathrm{C}$ and $765 \mathrm{D}$ penetrated 28 and $271 \mathrm{~m}$, respectively, into volcanic basement. Based on lithological and geochemical variations, 22 volcanic units were distinguished. The main lithologies recovered were (1) pillow basalt (54\%), (2) massive basalt (28\%), (3) diabase (4\%), (4) autoclastic breccia (6\%), and (5) tectonically brecciated pillow basalt $(8 \%)$. Despite this being one of the oldest sections of oceanic basement cored by ODP or DSDP, rock preservation is excellent. Fresh glass is present in pillow margins and within hyaloclastite breccia. Low-temperature alteration is not pervasive and is reflected in well-defined zones of $\mathrm{Fe}$-oxyhydroxide and celadonite that extend into the basalts from celadonite and/or calcite-filled fracture veins. Basalts 3 to $4 \mathrm{~cm}$ away from the low-temperature alteration halos have not been altered or are mildly altered.

The first igneous unit at Site 766 was encountered below 458 $\mathrm{m}$ of sediment and, because of the inclined nature of the contact and baking of the sediments, was interpreted as an intrusive sheet (Ishiwatari et al., this volume). This unit was underlain by an $8-\mathrm{m}$ interlayered sequence of 1 - to 1.5 -m-thick intrusions and dark green to dark gray siltstone. Below this sequence, coring recovered $60 \mathrm{~m}$ of diabase, again interpreted as a thick intrusion. Drilling was terminated while still within this intrusion, and Leg 123 scientists were unable to confirm the continuity of these intrusions with volcanic basement.

\section{SELECTION OF SAMPLES}

Initially, one sample from the top (123-765C-63R-4, 128-129 $\mathrm{cm})$ and one from the middle of the volcanic section $(123-765 \mathrm{D}$ $9 \mathrm{R}-2,28-30 \mathrm{~cm}$ ) drilled at Site 765 were analyzed. Both samples represent holocrystalline cores of pillow basalts that were rela- 


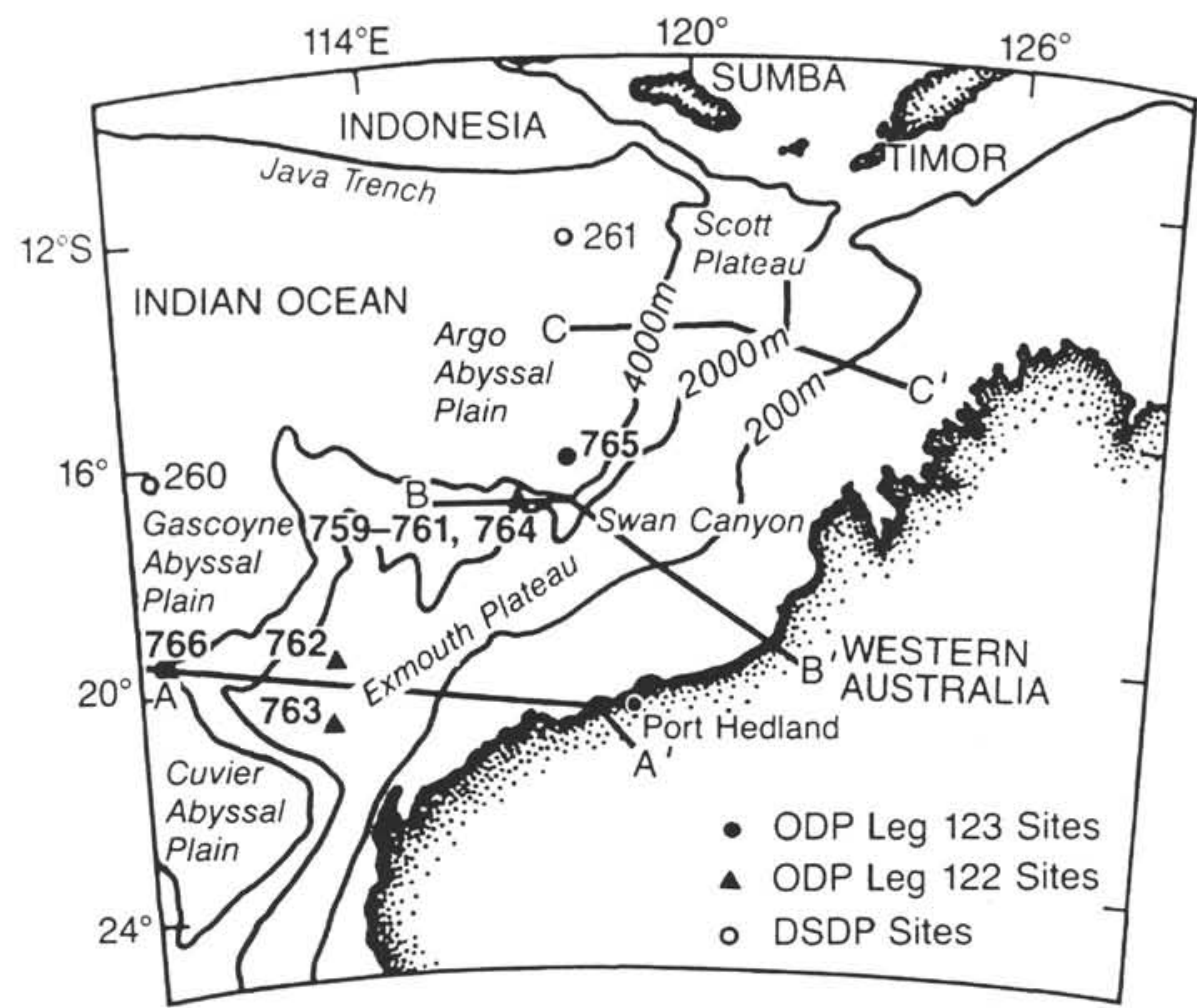

Figure 1: Location of Sites 766 and 765 on the northwestern Australian Margin and the Argo Abyssal Plain. Also shown are the locations of DSDP Sites 260 and 261 and Sites 762 through 764 drilled during DSDP and ODP legs.

tively unaltered. These samples were selected over the fresh basaltic glass found at Site 765 because of the possibility of loss of $\mathrm{Ar}$ in the glass. Because results obtained from these samples were inconsistent (see below), a piece of a celadonite vein was analyzed using conventional K/Ar techniques.

One sample from the unaltered diabase at the base of Site 766 was analyzed.

\section{RESULTS}

Results of analyses are presented in Table 1. Constants used for the calculations also are provided, and analytical techniques used have been described by Duncan and Hargraves (1990) and are based on techniques described initially by Dalrymple et al. (1981).

\section{Site 765 Holocrystalline Basalts}

Two ${ }^{40} \mathrm{Ar} /{ }^{39} \mathrm{Ar}$ heating experiments provided different totalfusion ages of $111 \pm 2 \mathrm{Ma}$ and $156 \pm 3 \mathrm{Ma}$. Both samples selected were relatively unaltered, and the inconsistency in the data is difficult to explain. Both samples (as for all the fresh basalts at Site 765 ) have low $\mathrm{K}_{2} \mathrm{O}$ values $(<0.1 \mathrm{wt} \%)$, and inconsistent results may simply be the result of difficulties inherent when obtaining reliable ages for low-K MORB tholeiites (see Duncan and Hargraves, 1990, and Dalrymple et al., 1981, for discussions).

\section{Site 765 Celadonite}

Despite an excellent degree of preservation for old oceanic crust, the basement has been altered by low-temperature seawater (Gillis et al., this volume). Several thick celadonite veins were separated and have been analyzed for major and trace elements and stable and radiogenic isotopes. A celadonite sample (123$765 \mathrm{D}-1 \mathrm{R}-02,30-34 \mathrm{~cm}$ ) was dated using the K/Ar technique and yielded an age of $155 \pm 3.4 \mathrm{Ma}$ (Table 2).
Table 1. Results of ${ }^{40} \mathrm{Ar}{ }^{39} \mathrm{Ar}$ heating experiments.

\begin{tabular}{|c|c|c|c|c|}
\hline $\begin{array}{c}\text { Sample } \\
(\mathrm{cm})\end{array}$ & Increment & $\begin{array}{l}{ }^{39} \mathrm{Ar} \\
(\%)\end{array}$ & $\begin{array}{c}{ }^{40} \mathrm{Ar} \\
(\%)\end{array}$ & Age $\pm 1 \sigma$ \\
\hline \multirow[t]{7}{*}{$123-765 \mathrm{D}-9 \mathrm{R}-2,28-30$} & 1 & 43.4 & 66.9 & $199 \pm 1$ \\
\hline & 2 & 7.1 & 63.8 & $92 \pm 6$ \\
\hline & 3 & 6.0 & 37.1 & $65 \pm 2$ \\
\hline & 4 & 7.7 & 16.5 & $46 \pm 2$ \\
\hline & 5 & 10.7 & 10.3 & $41 \pm 2$ \\
\hline & 6 & 25.4 & 12.3 & $20 \pm 1$ \\
\hline & \multicolumn{3}{|c|}{ Total fusion age } & $111 \pm 2$ \\
\hline \multirow[t]{7}{*}{$123-765 C-63 R-4,128-129$} & 1 & 43.9 & 54.6 & $217 \pm \quad 1$ \\
\hline & 2 & 18.4 & 35.7 & $156 \pm 2$ \\
\hline & 3 & 3.9 & 7.9 & $78 \pm 13$ \\
\hline & 4 & 4.4 & 4.9 & $115 \pm 13$ \\
\hline & 5 & 1.8 & 2.4 & $43 \pm 18$ \\
\hline & 6 & 27.7 & 5.7 & $78 \pm 2$ \\
\hline & \multicolumn{3}{|c|}{ Total fusion age } & $156 \pm 3$ \\
\hline \multirow[t]{7}{*}{$123-766 \mathrm{~A}-54 \mathrm{R}-3,67-75$} & 1 & 25.6 & 2.1 & $266 \pm 110$ \\
\hline & 2 & 17.5 & 1.4 & $155 \pm 33$ \\
\hline & 3 & 10.1 & 5.2 & $154 \pm 25$ \\
\hline & 4 & 18.7 & 2.0 & $130 \pm 28$ \\
\hline & 5 & 6.3 & 2.1 & $96 \pm 16$ \\
\hline & 6 & 21.8 & 1.0 & $65 \pm 25$ \\
\hline & \multicolumn{3}{|c|}{ Total fusion age } & $155 \pm 18$ \\
\hline
\end{tabular}

\footnotetext{
Note: Ages are calculated using the following decay and abundance constants: $\lambda_{\varepsilon}=0.581 \times 10^{-10} \mathrm{yr}^{-3}, \lambda_{\beta}=4.962 \times 10^{-10} \mathrm{yr}^{-1},{ }^{40} \mathrm{~K} / \mathrm{K}=1.167$ $\times 10^{-4} \mathrm{~mol} / \mathrm{mol}$.
}

\section{Site 766 Diabase}

Sample 123-766A-54R-3, 67-75 cm, gave an age of $155 \pm 18$ Ma. This dating overlaps with the Valanginian (138-131 Ma) predicted age of the opening of the Cuvier Abyssal Plain, based 
Table 2. Results of K-Ar dating of celadonite sample.

\begin{tabular}{ll}
\hline Sample & $123-765 \mathrm{D}-1 \mathrm{R}-02,30-34 \mathrm{~cm}$ \\
K (\%): & ${ }^{2} 4.807$ \\
Radiogenic ${ }^{40} \operatorname{Ar}(\%):$ & 86.0 \\
Age (Ma): & $155.3 \pm 3.4$ \\
\hline
\end{tabular}

a From $\mathrm{K}_{2} \mathrm{O}=5.791$ determined by DCP at LamontDoherty Geological Observatory (analyst, T. Plank).

on marine magnetic anomaly patterns (Sager et al., this volume) and biostratigraphy (Gradstein et al., this volume). However, the error for this age determination is large; this is probably a result of the extremely low abundances of $\mathrm{K}_{2} \mathrm{O}$ in this diabase sill $(0.05$ wt $\%)$.

\section{INTERPRETATION OF DATA}

Results from the basaltic samples are inconsistent and are probably a result of the difficulties encountered when determining ${ }^{40} \mathrm{Ar} /{ }^{39} \mathrm{Ar}$ ages in low $\mathrm{K}_{2} \mathrm{O}$ tholeiites. Similarly, the high error for the diabase sample from Site 766 reflects difficulties for obtaining reliable results from oceanic tholeiites.

The celadonite sample was selected because it is a high- $\mathrm{K}_{2} \mathrm{O}$ mineral, and its age should represent the age of the low-temperature alteration event that affected the crust and, thus, gives the minimum age of a basement formation. Similar secondary-mineral ages determined by Staudigel et al. (1981), Peterson et al. (1986), and Staudigel et al. (1986) for Cretaceous and Tertiary age oceanic crust and for the Cretaceous Troodos Ophiolite gave minimum ages that, in both cases, are up to $15 \mathrm{Ma}$ younger than the age of the formation of the crust. This celadonite age of $155 \mathrm{Ma}$ is consistent with the magnetic lineation age and the inferred older age of Site 765 relative to Site 261, given the northward opening of the Argo Abyssal Plain (Fig. 1).

The absence of biostratigraphic markers older than approximately 140 Ma may reflect erosion of sediments precipitated after the formation of ocean crust or may reflect a poorly preserved faunal assemblage in the lowermost sediments at Site 765 (see
Gradstein et al., this volume). While several questions remain unanswered, the radiometric dating experiments for the basement at Site 765 favor an age of at least $155 \mathrm{Ma}$, which is consistent with geophysical interpretations, but inconsistent with biostratigraphic results.

\section{ACKNOWLEDGMENTS}

These age determinations were performed at the College of Oceanography, University of Oregon, under the supervision of R. Duncan. I acknowledge B. Dionne for help with preparation of material for analysis. This work was supported by an NSERCCanada Collaborative Special Project Fund.

\section{REFERENCES}

Dalrymple, G. B., Lanphere, M. A., and Clague, D. A., 1981. Conventional and ${ }^{40} \mathrm{Ar} /{ }^{39} \mathrm{Ar} \mathrm{K}$-Ar ages of volcanic rocks from Ojin (Site 430), Nintoku (Site 432) and Suiko (Site 433) seamounts and the chronology of volcanic propagation along the Hawaiian-Emperor Chain. In Jackson, E. D., Koizumi, I., et al., Init. Repts. DSDP, 55: Washington (U.S. Govt. Printing Office), 659-676.

Duncan, R. A., and Hargraves, R. B., $1990 .{ }^{40} \mathrm{Ar} /{ }^{39} \mathrm{Ar}$ geochronology of basement rocks from the Mascarene Plateau, the Chagos Bank, and the Maldives Ridge. In Duncan, R. A., Backman, J., Peterson, L. C., et al., Proc. ODP. Sci. Results, 115: College Station, TX (Ocean Drilling Program), 43-51.

Ludden, J. N., Gradstein, F. M., et al., 1990. Proc. ODP, Init. Repts., 123 College Station, TX (Ocean Drilling Program).

Palmer, A. R., 1983. The decade of North American geology: 1983 geological time scale. Geology, 11:503-504.

Peterson, C., Duncan, R., and Scheidegger, K. F., 1986. Sequence and longevity of basalt alteration at Deep Sea Drilling Project site 597. In Leinen, M., Rea, D. K., et al., Init. Repts. DSDP, 92: Washington (U.S. Govt. Printing Office), 505-515.

Staudigel, H., Gillis, K., and Duncan, R., 1986. K/Ar and Rb/Sr ages of celadonites from the Troodos Ophiolite, Cyprus. Geology, 14:72-75.

Staudigel, H., Hart, S. R., and Richardson, S. H., 1981. Alteration of the oceanic crust: processes and timing. Earth Planet. Sci. Lett., 52:311327.

Date of initial receipt: 24 April 1991

Date of acceptance: 29 July 1991

Ms 123B-162 